\title{
Wilde's textbook covers the fundamentals of food system policy
}

\author{
Review by Michael Zastoupil*
}

Review of Food Policy in the United States: An Introduction (Second Edition), by Parke Wilde. (2018). New York: Routledge. Available as hardcover, paperback, and eBook; 278 pages. Publisher's website: https://www.routledge.com/Food-Policy-in-the-United-States-AnIntroduction-2nd-Edition/Wilde/p/book/9781138204003

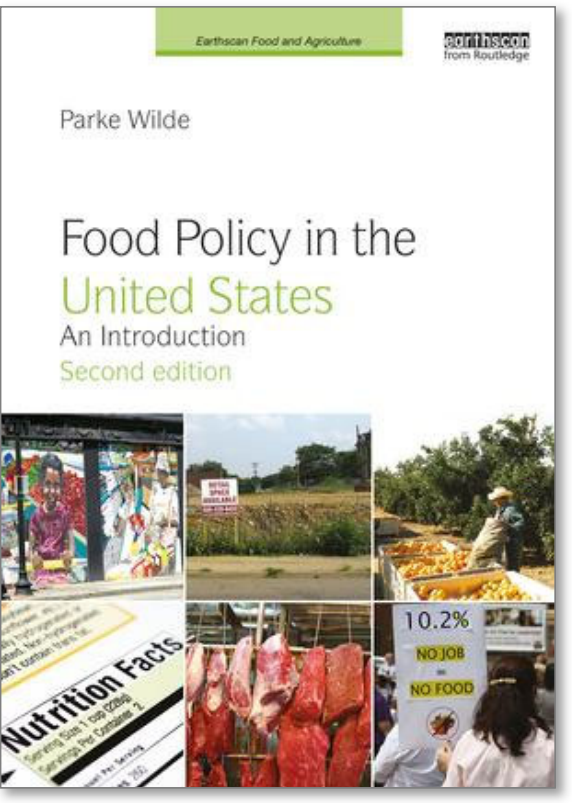

Submitted February 14, 2019 / Published online June 10, 2019

Citation: Zastoupil, M. (2019). Wilde's textbook covers the fundamentals of food system policy [Book review]. Journal of Agriculture, Food Systems, and Community

Development, 9(1), 135-136. https://doi.org/10.5304/jafscd.2019.091.007

Copyright (C) 2019 by the Author. Published by the Lyson Center for Civic Agriculture and Food Systems. Open access under CC-BY license.

$\mathrm{M}$ any of us who are interested in food systems reach a point in our learning journey where we realize that our government is involved in nearly every aspect of the food system. Whether you are passionate about nutrition, food justice, or climate change, you can bet there is at least one government regulation or program that signifi-

* Michael Zastoupil has been working in sustainable food systems since he started a Real Food Challenge club at North Dakota State University. Since then he has earned a master of science (M.S.) degree in Agriculture Food and Environment from Tufts University, where he took Parke Wilde's food policy class in 2016. While living in Boston, Michael worked for several different nonprofits on food system issues such as beginning farmer services, child garden and nutrition education, and farm-to-college programs. Since he and his wife are Midwesterners at heart, they have recently resettled in the Minneapolis area, where Michael is looking to get more involved in the local food system scene while working as an assistant manager at a Caribou Coffee store. He can be contacted at mzastoupil@gmail.com. cantly affects that issue. Parke Wilde's second edition of Food Policy in the United States: An Introduction is a comprehensive guide perfect for the graduate or undergraduate student who needs to understand the policy-making world. The book is not too different from the first edition, aside from updates based on recent policy changes in sources like the 2014 farm bill and the Dietary Guidelines for Americans 2015-2020.

The textbook does its best to cover every major food policy topic from "farm to fork." Before he begins, Wilde uses Chapter 1 to give the reader a crash course in the legislative process and some basic economic terminology, like "externalities." He also takes the time to explain that this textbook is written from a public-interest perspective and that the book tackles questions about both how policies should be made and how policies are actually made.

Chapter 2 starts out by giving a bird's eye view 
of U.S. agriculture. It provides an easy breakdown of all farms by categories like income and product, using charts and tables based on U.S Department of Agriculture (USDA) data. It's only natural that Chapter 3 talks about the environmental consequences of the agricultural production described in Chapter 2. The majority of the chapter covers the most pressing environmental challenges one at a time, such as water scarcity and pollution, and the government policies that attempt to address them, such as the Clean Water Act. Since food systems are ultimately global, Chapter 4 is focused on international trade. Wilde uses economic models to explore several real-world trade situations, such as tariffs on U.S. corn exports to other countries and the impact of U.S. sugar subsidies on global sugar prices.

With each chapter, Wilde introduces a few more economic concepts to the reader using actual examples, such as the property rights dilemma inherent in fisheries. When possible, he also summarizes the major types of policy tools that are used according to their economic impact. For the novice trying to understand why crop insurance is different from direct payments to farmers, for example, these sections are instructive.

Chapter 5 covers the food manufacturing industry, focusing on the sector's long history of market power concentration and exploring economic concepts such as monopoly vs. monopsony and related antitrust regulations. Chapter 6 takes a look at the food retail and restaurant industries, examining issues such as food deserts, minimum wage laws, and the influence of price on consumers' food choices. Chapter 7 explains how food safety is regulated, including how risk is managed in the face of incomplete information and why cheese pizza is actually regulated by a different federal agency than pepperoni pizza.

While Wilde writes with the unbiased, evidence-based rigor of an economist, occasional flashes of his activist inclinations shine through. When writing about topics close to the heart of his own work, such as food labeling, Wilde writes with the chagrin of a policy advocate who has seen too many important food policy issues gridlocked in partisan debates for years. And yet he is still optimistic, dedicating the entire last chapter to all the ways that new advocacy coalitions and research can continue to improve U.S. food policy.

Chapter 8 explains in detail how the Dietary Guidelines for Americans is determined and why it is needed based on chronic disease trends. Chapter 9 unravels the messy legal issues involved in food labeling and advertising and the associated imperfect information problems. Chapter 10 describes hunger and food insecurity in the context of poverty and examines the economics of Supplemental Nutrition Assistance Program (SNAP) nutrition assistance for adults, while Chapter 11 explores nutrition assistance programs for children.

Wilde's writing style makes this textbook perfect for the student or food activist taking a comprehensive look at food policy for the first time. He writes clearly and concisely, using the tone of a natural teacher-approachable, intuitive, and supported by robust evidence. My only critique is that the textbook could benefit from more attractive visuals to explain its complex topics, beyond plain tables and charts. The use of boldface for key terms throughout the chapters is quite helpful, as are the sidebars with brief, real-world economic problems and stories. For those students who read everything and still want more, the companion website is an excellent source of additional information, news, and problem sets. 